\title{
EXTRACTION AND CHARACTERIZATION OF PROTEINS FROM CELL WALLS OF TWO STRAINS OF Paracoccidioides brasiliensis.
}

(Extracción y caracterización de proteínas de pared celular de dos muestras de Paracoccidioidles brasiliensis)

\author{
Kaoru Okada ${ }^{1}$; Isaíras Padovan ${ }^{2}$; \\ Kazutaka Fukushima, ${ }^{+} ;{ }^{*}$ Galb th Maria de Campos -Takaki ${ }^{1,3}$ \\ Laboratório de Imunopatologia Keizo Asami ${ }^{1}$ \\ Departamento de Histologia ${ }^{2}$ - Departamento de Antibióticos ${ }^{3}$ \\ Research Center of Pathogenic Fungi and Microbial Toxicoses, \\ Chiba University, Japan ${ }^{4}$
}

Key words: Paracoccidioides brasiliensis, proteins, gp 43 , cell walls.

Palab ras clave: Paracoccidioides brasiliensis, protcinas, gp +3 , pared cclular.

\section{SUMMARY}

In the present paper we analyzed the proteins from the cell walls of 2 strains of Paracoccidioides brasiliensis (PbHC-PE and Ph 18) underveast-phase. The proteins were extracted by thee different methods and were studied by electrophoresis SDSS-PAGE. Results of profiles from the wro studied strains were different allowing them to be used as chemotaxomomic marker. The transitory secretion of protein gp +3 through the cell wall of both P. brasiliensis strains was observed.

\section{INTRODUCTION}

Paracoccidioides brasiliensis is a thermally dimorphic pathogenic fungus, which is the responsible agent for paracoccidioidomycosis, a deep systemic mycosis occurring in Latin America (8. 19.24). It develops into a ycast phase at $37^{\circ} \mathrm{C}$, while at $23^{\circ} \mathrm{C}$ grows as a mycelial $(6,7,8,22,28)$. The temperature induced a differentiation process readily reversible and cell wall polysaccharide

\section{RESUMEN}

En el presente trabajo se analizaron las proteinas de la pared celular de 2 cepas de Paracoccidioides brasiliensis en fase levaduriforme (PbHC-PE y Pb 18). Las proteinas fueron extraidas por tres diferentes métodos y estudiadas por electrofóresis SDS-PAGE. Los resultados de los perfiles de las dos cepas fueron diferentes, permitiendo la posibilidad de su uso como marcadores quimiotaxonómicos. Se observó una secreción transitoria de la proteina gp 43 a través de la pared celular de las cepas de P. brasiliensis.

composition between the cell types $(9,10)$. The yeast cell wall polysaccharide is mainly composed of a high content of alpha-1, 3-glucan (95\%) and a small amount of alkaliinsoluble beti-1, 3-glucan (5\%). The opposite is observed for the mycelial phase and the content of chitin is about the same to both dimorphic states $(6,29)$. The protein content of the $P$. brasiliensis cell wall, represents $24-41 \%$ and 18 $27 \%$ of the mycelial and yeast phase, respectively $(13,25)$.

*Corresponding Author: Dr. G. M. Campos-Takaki, Universidade Católica de Pernambuco. Rua de Principe, 546 Boa Vista. Recifc, Pcrnambuco, BRASIL CEP 5()()5()-9(0) 
This paper reports methods for the solubilization of $P$. brasiliensis cell wall protcins by detcrgents. cnzy'matic digestion, and their analyses on SDS-PAGE.

\section{MATERIALS AND METHODS}

Strains, medium, and growth conditions: $P$. brasiliensis strains $\mathrm{Pb} 18$ and $\mathrm{PbHC}$-PE used in this work were isolated at the Clinical Hospital of the Federal University of Pernambuco, Brazil (PbHC-PE) and obtained from Dr. Aparecida Resende collection. Federal University of Minas Gerais, Brazil. Thecells were grown in SABHI (Sabouraud, brain heart infusion) medium, modified by adding $1 \%$ of yeast extract and shaked at 200 rpm at $366^{\circ} \mathrm{C}$ for 10 days

Extraction and purilication of the cell walls: Cells were washed five times with distilled water, twice with 10 mMTris-HCIbuffer ( $\mathrm{pH}$ 7) containing $1 \mathrm{mM}$ phenỵl methyl sulphonyl fluoride (PMSF). Cells were broken with glass beads $(425-600 \mathrm{~mm})$ by shaking five times in vortex mixer for $30 \mathrm{~s}$. The cell fragments were collected by centrifugation $(1800 \mathrm{~g})$ for $10 \mathrm{~min}$, resuspended in the sime buffer and centrifuged once morc.

The cells were sonicaied $20 \mathrm{KH} /$ for $15 \mathrm{~min}$, in a cold bath. twice. and washed five times with 10 mM Tris- $\mathrm{HCl}$ buffer, $\mathrm{pH} 7$, containing $1 \mathrm{mM}$ ofPMSF. The walls obtained were purified, the purity was confirmed by the transmission electron microscopy according to the method described by Campos-Takaki $(+, 5)$.

The protcins were solubilized as follows:

Method 1. as follows:

The method described by Pastor et al. (20) modified

a) Pre-treatment. Total cells and cell walls were initially pre-Ircalcd with 100$) \mathrm{mMTris}-\mathrm{HCl}, \mathrm{pH} 8$, containing $5 \mathrm{mMDL}$-dithiotrcitol and $5 \mathrm{mM}$ EDTA for 3() $\mathrm{min}$ at $28^{\circ} \mathrm{C}$.

b) SDS treatment. The cells and cell walls were then cent rifuged at $1.80(0 \mathrm{xg}$ for 10 min and treated with $2 \%$ SDS prepared in $10 \mathrm{mM}$ Tris- $\mathrm{HCl}$ buffer. $\mathrm{pH} 7$, at 10()$^{\circ} \mathrm{C}$ for $5 \mathrm{~min}$.

c) Zymolase treatment- The cells and cell walls were again centrifugated at $1.80(0) \mathrm{xg}$ for 10 min and the residual fraction was treated with $2 \mathrm{mg} / \mathrm{ml}$ Zymolase (Sigma Chemical Co.). prepared in 1() $\mathrm{mM}$ Tris-HCl buffer. $\mathrm{pH} 7$, for $3 \mathrm{~h}$ at $28^{\circ} \mathrm{C}$. Ammonium sulfate was added to the supernatant of cach treat ment of the total cells until $60 \% \%$ and $90 \%$ of saturation were achicied in order to recorer the solubilizcd protcins.

Method 2.

The method was described by Herrero et al. (12) modificd as follows: The walls werc init ially pre-treatcd with 10) mM Tris- $\mathrm{HCl}, \mathrm{pH} 8$, containing $5 \mathrm{mMDL}$-dithio-trcitol and $5 \mathrm{mM}$ EDTA, for 30 min at $28^{\circ} \mathrm{C}$. The walls were then centrifuged and treated with zymolase $(2 \mathrm{mg} / \mathrm{ml}$ in $10 \mathrm{mM}$ Tris-HCI buffer pH 7) for $3 \mathrm{~h}$ at $36^{\circ} \mathrm{C}$.

\section{Method3.}

Modificd after Kobayashi et al. (14). Cell wall proteins were obtained by zymolase treatment of the $\boldsymbol{P}$. brasiliensis cells in osmotical stabilized buffrer. The cells wercpre-tratcd with $100 \mathrm{mMTris}-\mathrm{HCl}$ bufferpH 8 , containing $5 \mathrm{mM}$ EDTA and $5 \mathrm{mM}$ DL-dithiotreitol for $30 \mathrm{minat} 28^{\circ} \mathrm{C}$. Subsequently, the cell walls were washed 4 times with 0,67 $\mathrm{mM}$ potassium phosphate buffer, $\mathrm{pH} 7,5$. containing $1,5 \mathrm{M}$ sorbitol, then incubated in shaker with zymolase ( $2 \mathrm{mg} / \mathrm{ml})$ in the same buffer for 5 h at $36^{\circ} \mathrm{C}$. Afterwards, the preparation wascentrifuged at $10.000 \mathrm{xg}$. for $10 \mathrm{~min}$, and the supernatant was kept for protcin detcrmination.

The electrophoresis of the protcins obtained according to the three procedures described above was carricd out in polyacrylamida gel horizontal flatbed system as described by Lacmmli (15).

The protein contents were established according to Lowry et al. (16), using bovine scrum albumin as standard.

\section{RESULTS}

The method proposed by Pastoret al.(20), modificd in this work (Method I) showed to be the most efficient to c.tract protcins from the $P$. brasiliensis, as it can be seen in Table 1.2 and 3 . The amount of protein extracted from the strain Pbl8 according to Method 1 showed to be similar in all treatments. On the other hand, the SDS treatment did not present the same performance for the protein solubilization of the PoHC-PE strain. Table I also shows that the best protcin precipitation was achicred with 9$) \%$ of ammonium sulfatc saturation. cxcept for the SDS step. However, the SDS supernatant (Mcthod I) protcins from the isolated cell walls of both strains was the best (Table 2).

Seren bands were obtained in the electrophoresis in protein profilc of both strains using any of the treatments tesied from appear molecularweights $+8,42,34,29,21$ and 16 (Figures $1 \mathrm{~A}_{1}$ ).

Otherwisc. the fractions precipitated with ammonium sulfatc 6()$\%$ and $90 \%$ showed similar results to $\mathrm{PbHC}-\mathrm{PE}$ and $\mathrm{Pb} 18$ (Table 1 ).

The clectrophoretic profiles indicated bands from $6610 \mathrm{I} 2 \mathrm{kDa}$ (Figure $1 \mathrm{~A}_{2}$ ). The isolatcd cell walls proteins from $\mathrm{PbHC}-\mathrm{PE}$ and $\mathrm{Pb} 18$ showed bands with $66 \mathrm{kDa} .45$ kDa. I kDa.37kDa26kDa, 2+kDa. and I+kDa, cxcept the 4.3 kDa band which occurred only on the PbHC-PE strain (Tables 2 and Figure $2 \mathrm{~A}$ ). In the last methodology applied band with molecular weight similar to 21 kDawas identificd (Table 3 and Figure $2 \mathrm{C}$ ). 
Talble 1.

Protein concentration of P. brasiliensis yeast cell extractsobtained by Method 1.

\begin{tabular}{|c|c|c|c|c|c|c|}
\hline \multicolumn{7}{|c|}{ Protein content (\%) } \\
\hline \multirow{3}{*}{ TREATMENT } & \multicolumn{2}{|c|}{ Supernatant } & \multicolumn{4}{|c|}{ Precipitated with ammonium sulfate } \\
\hline & \multirow[b]{2}{*}{ PIDHC-PE } & \multirow[b]{2}{*}{ Pl) 18} & \multicolumn{2}{|c|}{ PHHC-PE } & \multicolumn{2}{|c|}{ Pb 18} \\
\hline & & & $(x) \%$ & $9(0) \%$ & $60 \%$ & $90 \%$ \\
\hline Prc-tratment & +1.5 & .34 .5 & 10,32 & 22,28 & 13,38 & 25,52 \\
\hline SDS & 9.5 & $26 .+$ & 0.38 & 13.86 & 23,95 & 9,12 \\
\hline Zymolase & 4). () & 39.1 & 8.97 & 27.18 & 8.68 & $18,9+$ \\
\hline
\end{tabular}

Method 1. Pastor et al. (21) modilied.

Talble 2.

Protein concentration of $P$. brasilicnsis cell wall extracts solubilized by Method 1

\begin{tabular}{|l|c|c|}
\hline \multicolumn{3}{|c|}{ Proteincontent (\%) } \\
\hline TREATMENT & Pl)HC-PE & Pb 18 \\
\hline Prc-trcatment & 2.9 & 2.5 \\
SDS 2\% & 3.5 & 3.5 \\
Zymolasc & 1.4 & 1.3 \\
\hline
\end{tabular}

Method 1, Pastor et al. (21)

Table 3.

Protein concentration of P. brasiliensis extracts solubilizedby Method 2 and 3

\begin{tabular}{|l|cc|c|}
\hline \multicolumn{3}{|c|}{ Protein content (\%) } \\
\hline Strains & \multicolumn{2}{|c|}{ Method2 } & Niethod3 \\
\hline & Pre-tratment & Zymnolase & PthHC-PE \\
\cline { 2 - 4 } PIHC-PE & 4,2 & 1,4 & 1,3 \\
Pb 18 & 4,0 & 1,0 & 1,2 \\
\hline
\end{tabular}

Method 2: Herrero et al. 1987 (12), modified. Method 3: Kobayashi et al. 1984(14), modified.

The cxtraction of proteins of cells walls from the whole cell showed low level of protein and bands with $23 \mathrm{kDa}$. $38 \mathrm{kDa} .45 \mathrm{kDa}$ and $48 \mathrm{kDa}$ (Table.3. Figure $2 \mathrm{~B}$ and $\mathrm{C}$ ).

\section{DISCUSSION}

Recently. there has becn an increase in research of the biochemistry. physiology, and mechanism of pathogenicity with the purpose of elucidat ing the responses of the infected host (10. 17, 18,21.23,24,25). The cell wall has been recognized in molecular studies as the first step concerning host-parasitc relationships $(21,24,25,28)$.

Thic litcrature suggested the cell wall structures and their influence in host parasitism process as follows: protcins. glycoprotcins. carbolyydrates, and lipids $(16,17$. 20. 23). On the other hand. the electrophoresis applied to fungal proteins has received much attention in last years (11. 14.26.27). The electrophoresis has now been applied to members of every major of the fungi (27), and the technique is antaltemp to understand better the taxonomic rclationship of organism (1).

The Pastor et al. (20) method. modificd utilizing whole cells of $P$. brasiliensis showcd protcins than described by Herrero et al. (12) method-SDS, which solubilizes less proteins than pre-treat ment and $\%$ molase, though. The electrophoretic palterns showed discrect bands in both samples. after ammonium sulfate precipitation.

On intact cells zymolase treatments relcased low Icrel of proteins and showed four bands in PbHC-PE and three bands in $\mathrm{Pb} 18$. The presence of a band $+3 \mathrm{kD}$ a may be transitory at the location before being integrated into c.tracellular metabolite. This would cxplain the observation suggested that $+.3 \mathrm{k}$ a band is secreted to the medium $(2.3)$.

The isolated walls showed less proteins after pretreatment in both samples by the method modified by Herrero et al., (12) method 2. The ycast form of $P$. 

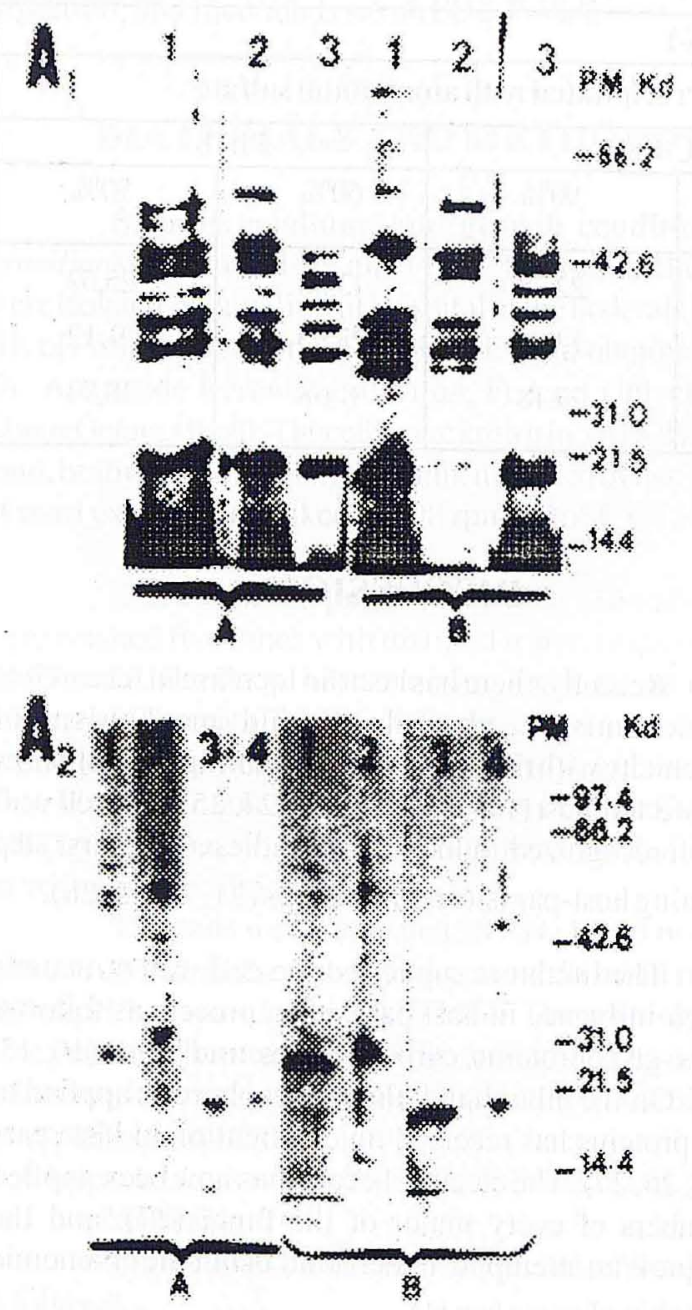

Figure 1: Elcctrophoresis profile in SDS-PAGE of prolcins obtained by Method 1 from cellular cxtract of $P$. brasiliensis PbHC-PE (A) Pb 18 (B) samples. A 1: 1 - Fraction obtained after pre-trcatment; 2 -Fraction solubilized with $2 \%$ SDS; 3 - Fraction solubilized with zymolase. A2: supernatant obtained with 60 and $90 \%$ of ammonium sulfate precipitation, 1-2 -Fraction obtained after pre-treatment; 3 -Fraction solubilized by zymolase.

brasiliensis surface cxhibited cight bands in PbHC-PE and sixbands in Pb 18. Similarprotcins of the 2 I kDa were detected in both samples, and the proteins of the $43 \mathrm{kDa}$ occurs in PbHC-PE. This molecule probably' corresponds to glycoprotcin of the $43 \mathrm{kDa}$, in its routc of secretion, across the cell wall.

The translocation of proteins across the vesicle membrancs has becn observed in cell-frec systems for ycast and higher eukaryotes proteins.

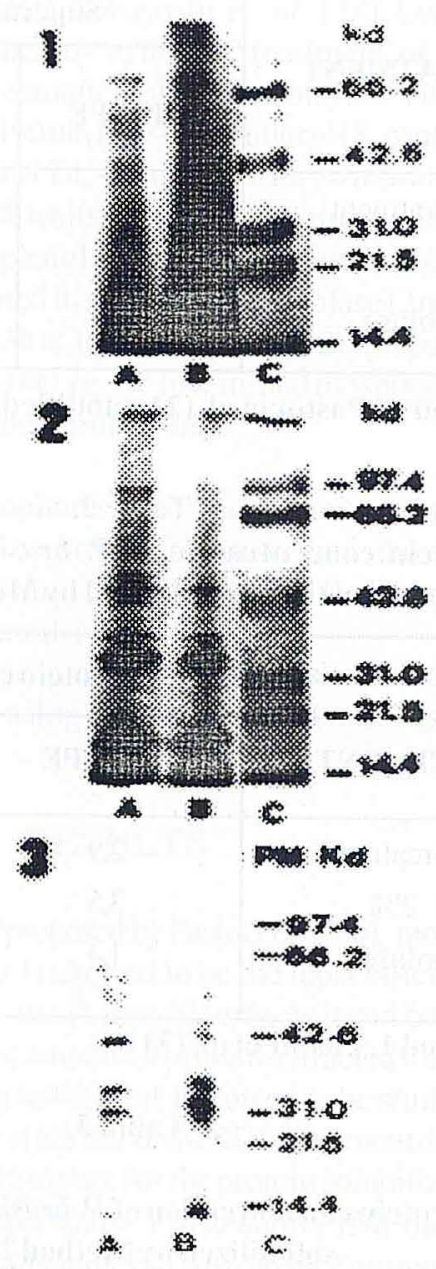

Figure 2. SDS-PAGE profilc of protcins solubilized by method 1 (1), Method 2 (2) and Method 3 (3) from cell walls of $P$. brasiliensis $\mathrm{PbHC}-\mathrm{PE}(\mathrm{A})$ and $\mathrm{Pb} 18(\mathrm{~B})$, and standards $(C)$.

Results described in this paper, therefore, show that the electrophoretic pattern of the proteins in yeast cell wall of P. brasiliensis and the gp +3 transitory extracellular antigens throw out of the wall

\section{AKNOWLEDGMENTS}

The authors are grateful to FINEP, FACEPE, CNPq (30). 1+26-81), PRONEX, JICA, for financial support and S. H. Almeida for technical assistance. 


\section{REFERENCES}

1.- Berry, J. A. \& Franke, R. (.. (1973). Tiaxonomic signilicance of ultraspecilic isozyme patterns of the slime mold finligo setica produced by disc electrophoresis. Am. J. Botany 6():976-986

2.-Camargo, Z. P.; Unterkircher, C. \& Travassos, I. R. (1989). Identification of antigenic polypeptides of Paracoccidiodes brasiliensis by inmunoblotting. J. Medical. Vet. Mycol. 27:407-412

3.- Campos, M. C.; Gesztesi, J. L.; Vincentini, A. P. ; Lopes, J. D. \& Camargo, Z. P. (1995). Lxpression and isoforms of gpt3 in different strains of Paracoccidioides brasiliensis. I. Med. Vet. Mycol. 33:22.3-227

4.- Campos-Takaki, C. M. (1984). Aspectos biocuimicos e ultraestruturais das paredes celulares de lunges da ordem Mlueorales (Zygonyectes). Tese de Doutorado em Microbiologia e Imunologia pela Escola Paulista de Medicina.

5.- Campos-Takaki, G. M.; Dictrich, S. M. C. \& Manocha, M. (1989). The influence of culture age on the shemical cell wall of Elisomyces anomalum. Rev. de Microbiologia. 20:321-326

6.-Carbonell, L. M.; Kanetsuna, F. \& (iil, F. (197()). Chemical morphology of gluean and chitin in the eell wall of the yeast phase of P'aracoccidioides brasiliensis. J. Bacteriology 101:6,36-642

7.- Carbonell, I. M. \& Rodrigue\%, J. (1968). Mycelial phase of Paracoccidioides brasiliensis and Blastomyces dermatitidis an electron microscopic study. J. Batcteriology 96:53.3-5.34

8.- Del Negro, G.; Lacaz, C.. S. \& Fiorillo, A. M. (1982). Paracoceidioidomicoses: 13lastomicose Sul-Americana. Sia Paulo, Savier.

9.- Figueroa, J. L.; IIamilton, A.; Alicn, M. \& R. IIay (1995). Isolation and partial charaterization of a Paracoccidioides brasiliensis $58 \mathrm{kD}$ a extracellular glycoprotein which is recognized by human seral. Trans. R. Soc. Trp. Med. Ilyg. 89:566-572

10.- Furtado, J. 5.; Brito, T. de lireyuller, E. (1967). The structure and reproduction of P'aracoccidiodes brasiliensis in human tissue. 5:226-229

11.- IIall, R. (1971). Molecular approathes to taxonomy of fingi. Bot. Rev. 35:285-304

12.- IIerrero, E., Sanzs, P., Sentandreu, R. (1987). C'心ll waII proteins liberated by zymolase from several Ascomyeetes and imperfect yeasts. J. Gen. Microbiol. 133:2895-2\%().3

13.-Kanctsuna,F.: Carbonell,L.M.; Moreno,R.E.;R odrigue\%,J. (1969). Cell wall composition of the yeast and mycelial forms of Paracoccidiatides brasiliensis. I. Bacteriology 97:1(036-1(1)+1

14.-Kobayashi, K. \& Suginaka, II. (1984). Comparation of eell wall and membrane proteins from eight Candida species. Sabouratudia $22: 341-344$

15.- Laemmli, U. K. (197()). Cleyage of the structural proteins during the assembly of the head of bacteriophage- T4. Nature 227: $680-685$

16.- Lowry, O. II.; Rosenbrough, N. J.; Farr, A. L. \& Randall,
R. J. (1951). Protein measurement with the Folin phenol reagent. J. Biol. Chem. 193:265-275

17.- Manocha, M. S. (1975). Host-parasite relations in a mycoparasite III. Morphological and biochemical differences in the parasitic and axenic cultures spores of Piptocephalis virginiana. Mycologia 67: 382-391

18.- Manocha, M.S. (1981). Host specificity and mechanism of resistance in mycoparasite system. Physiol. Plant Pathology 18:257265

19.- Mckwen, J.G.; Garcia, A.M.; Ortiz, B. L.; Botero, S. \& Restrepo, A. (1995). In sea th of natural habitat of Paracoccidiogides brasiliensis Arch. Med. Res. 26:305-306

20.- Pastor, F. I. J.; Valetin, E. \& IIerrero, E. (1984). Structure of the Saccharomyces cerevisiae ell wall: mannoproteins released by zymolase and their contribution to wall architecture. Biochi. Biophy. Acta 8(2)2:292-30)

21.- Ra:i, J. \& Robertson, M.\& Solheim, B. (1977). Cell surface biochemistry related to specilicity of pathogenesis and virulence of microorganisms. In cell wall biochemistry related to specificity in host-plant pathogen interaction. Solheim, B3.; Rata. J. (Eds), Tronson. Oslo, Bergen. pp.11-30

22.- Restrepo, M. A. (1970). Reappraisal of the microscopial appearance of the mycelial phase from P'aracoccidioides brasiliensis. Sabouratudia $8: 141-144$

23.- Salcm-Itace, S.M.; Jesuino, R. S.; Brito, W. A.; Pereira, M.; Felipe, M. S. \& Soares, C. M. (1997). Protein synthesis patterns of Paracoccidioides brasiliensis isolates in stage-specific forms and during cellular diflerentiation. J. Med. Vet. Mycol. 35: 205211

24.- Siln-Blas, G. (1982). The cell wall of fungal human pathogens: Its possible role in hostparasite reiationships A review. Mycopathologia 79:159-184

25.- San-Blas, G. \& San-Blas, F. (1977). Paracoccidioides brasiliensis: ceil wall structure and virulence. A review. Mycopathologia 62:77-86

26.- Schehter, Y.; Landau, J. W. \& Dabrona, N. (1972). Comparative electrophoresis and numerical taxonomy of same Candida species. Mycologia 64:841-853

27.- Tyrel, D. (1971). Biochemical systematies and fungi. Bot. Rev. $35: 305-316$

28.- Villar,I....; Salazar,M.E. \& Restrepo,A.(1988). Morphologiwal study of a variant of Paracoccidiodes brasiliensis that exist in the yeast form at room temperature. J. Med. Vet. Mycol. 26:269-276.

29.- Vincentini, A. P.; Gesztesi, J. L.; Franco, M. F.; de Souza, W.; Moracs. J. Z.; Travassos, L. R.; Lopes, J. D. (1995). Binding of Paracoccidioides brasiliensis to laminin through surface glycoprotein gp 43 leads to enhancement of fungal pathogenesis. Infect. Immun.62:1465-1469 